\title{
Production of the Antiserum against Recombinant Envelop Protein, rVP466 for the Neutralization of White Spot Syndrome Virus (WSSV)
}

\author{
Soo-Jung Gong ${ }^{1}$, Yeong Jin Kim, Mi Ran Choi and Sung-Koo Kim* \\ Department of Biotechnology, Pukyong National University, Busan 608-737, Korea \\ ${ }^{1}$ Research Center, Binex, Busan 604-846, Korea \\ Received June 14, 2010 /Accepted October 14, 2010
}

\begin{abstract}
This study was carried out to evaluate neutralization effects against WSSV using antiserum produced from recombinant envelop protein, rVP466 of WSSV. The VP466 gene of WSSV was cloned into pCold I expression vector and rVP466 was expressed in E. coli RIPL. The antiserum against rVP466 was produced in white rabbits (New Zealand white rabbit). The specific immunoreactivity to the antigen, rVP466, was confirmed by Western blot. The constant amounts of WSSV at $1 \times 10^{4}$ diluted stocks were mixed with various antiserum concentrations and then injected to the muscle of shrimp, Penaeus chinensis, for the neutralization challenge. The shrimps challenged with WSSV as a positive control and those with the mixture of WSSV and preimmune serum as a preimmune control showed $100 \%$ cumulative mortality at 17 days post challenge and $83 \%$ at 25 days post challenge, respectively. The shrimps challenged with 3 different mixtures of WSSV and rVP466 antiserum at ratios of 1:0.01, 1:0.1 and $1: 1$ showed $73 \%, 53 \%$ and $46 \%$ cumulative mortalities at 25 days post challenge, respectively. These results indicated that WSSV could be neutralized by the rVP466 antiserum. These results suggest that envelop protein VP466 is involved in the initial step of WSSV infection in shrimp.
\end{abstract}

Key words : White spot syndrome virus (WSSV), VP466, antiserum, neutralization

\section{Introduction}

White spot syndrome virus (WSSV), $305 \mathrm{~kb}$ double-stranded DNA virus belongs to monotypic family Nimaviridae, genus Whispovirus with a wide host range among crustaceans [11]. WSSV infection causes $100 \%$ mortality within 7 to 10 days in commercial shrimp culture pond, resulting in large economical losses to the shrimp culture industry [14].

The envelop proteins of virus usually play important roles in virus infection and assembly [7]. Therefore, envelop proteins can be a useful tool to produce antibody and vaccine. It has been regarded that a true adaptive immune response system lacks invertebrates except innate immune responses like cellular immunity. However, the recent reports suggested that short-term memory adaptive immune response exists in shrimp as a defense system against infection [10].

The virus particle of WSSV consists of 6 major proteins such as VP15, VP19, VP24, VP26, VP28 and VP664. In addition to major proteins, 40 WSSV proteins have been characterized [2]. The VP466 gene is located at 177124-178521 of WSSV genome (Genbank accession no. AF395545). The open

\footnotetext{
*Corresponding author

Tel : +82-51-629-5868, Fax : +82-51-629-5868;

E-mail : skkim@pknu.ac.kr
}

reading frame (ORF) of VP466 gene is composed of a 1381 bp fragment encoding a protein of 466 amino acids with a deduced molecular mass of about $50 \mathrm{kDa}$ [6].

Neutralization assays have been performed to study the role of virion proteins in the infection stage. Antibodies bind to the envelop protein of the virion, thus prevent the attachment of virus on the cell surface, entry to cell or virus uncoating [1]. In vivo neutralization has been widely used for many vertebrate viruses and passive immunization strategies. Musthaq et al. used a recombinant WSSV envelop protein, $\mathrm{rVP} 28$ to evaluate the potential for the neutralization of WSSV [7].

In this study, the productions of antiserum against recombinant envelop protein, rVP466 and neutralization of WSSV was carried out to elucidate infection mechanism of VP466 of WSSV.

\section{Materials and Methods}

\section{Shrimp culture}

Healthy shrimps (Penaeus chinensis) were purchased from a shrimp farm located in Goheung, Jeonnam, Korea. Shrimps of 6 to 8 grams were used in experiments. Shrimps were kept in tanks at $26^{\circ} \mathrm{C}$ and each shrimp was placed in individual plastic cages to prevent cannibalism [13]. Polymerase 
chain reaction (PCR) was carried out with WSSV-specific primers to ensure previous WSSV exposure before experimental infection.

\section{WSSV stock and virus titration}

WSSV infected shrimps were homogenized in 10-fold volumes of phosphate buffered saline (PBS) at $4^{\circ} \mathrm{C}$ and centrifuged at $12,000 \times \mathrm{g}$ for $10 \mathrm{~min}$ at $4^{\circ} \mathrm{C}$. The supernatant was filtered through a $0.45 \mu \mathrm{m}$ filter and the filtrate was used the virus stock for challenge test.

The virus stock was serially diluted from $1 \times 10^{1}$ to $1 \times 10^{7}$ times in PBS. Twenty-five microliters of different virus dilutions were injected in the second abdominal segment of the shrimp using a 30-gauge needle. For each group, ten shrimps were used in the challenge test. Mortality was recorded daily and dead shrimps were tested for the presence of WSSV by PCR. The time-mortality relationship was used to determine an optimal challenge pressure for the neutralization assay.

\section{Construction of recombinant plasmid, pCold-VP466} WSSV genomic DNAs were extracted from the WSSV stock using Genomic DNA Extraction Kit (Bioneer, Daejeon, Korea). The VP466 specific primer sets of forward primer 5'-GGATCCATGTCTGCATCTTTAATATTGGAC-3' and reverse primer 5'-AAGCTTGTTATGACACAAACCTATTCCACAA-3' with $B a m \mathrm{H}$ I and Hind III restriction site, respectively, were prepared based on the nucleotide sequences of VP466. The DNA fragment encoding the entire VP466 ORF was amplified from WSSV genomic DNA by PCR.

PCR was performed under following conditions: $95^{\circ} \mathrm{C}$ for $5 \mathrm{~min}, 30$ cycles at $95^{\circ} \mathrm{C}$ for $30 \mathrm{sec}, 55^{\circ} \mathrm{C}$ for $30 \mathrm{sec}$ and $72^{\circ} \mathrm{C}$ for $30 \mathrm{sec}$, followed by an extension period at $72^{\circ} \mathrm{C}$ for 5 min. The amplified VP466 of 1,381 bp DNA fragments was cut by same restriction enzyme BamH I and Hind III. The VP466 gene was inserted into cold-shock expression vector, pCold I (Takara, Shiga, Japan). The presence of the insert in the plasmid was confirmed by colony PCR and digestion with BamH I and Hind III.

The recombinant plasmid was sequenced at Macrogen. Ltd. (Seoul, Korea). The comparison of nucleotide sequence of VP466 gene was performed with BLAST (NCBI, USA). The resulting recombinant plasmid was named pColdVP466.

Bacterial expression and purification of recombinant protein VP466 (rVP466)

The recombinant plasmid, pCold-VP466, was inserted into
E. coli RIPL and the protein was expressed by the addition of $0.5 \mathrm{mM}$ IPTG for $3 \mathrm{hr}$ at $37^{\circ} \mathrm{C}$. Cells were disrupted by the sonication with $8 \mathrm{M}$ urea, and then centrifuged at $12,000 \times \mathrm{g}$ for $20 \mathrm{~min}$ at $4^{\circ} \mathrm{C}$. The expression of recombinant protein, VP466 was confiremed using SDS-PAGE (12\% acrylamide gel). Most of the expressed protein was solubilized from inclusion bodies. Dialysis of the supernatant was carried out in TE buffer (50mM Tris, 20mM EDTA, pH. 8.0) using the membrane with molecular weight cut off of 12,000-14,000 (Spectrum Laboratories, Inc., Houston, USA) to remove the urea. The concentration of protein was determined by the Bradford assay (Bio-Rad, Hercules, USA).

For the antiserum production, (His) 6 -tagged rVP466 was purified using a Ni-Sepharose high performance resin open column (GE Healthcare Bio-science, Uppsala, Sweden). The purified protein was further concentrated by Amicon Ultra 30K (Millipore, Bedford, USA). The molecular weight of purified rVP466 was determined by SDS-PAGE (12\% acrylamide gel), and the concentration of protein was determined by the Bradford assay (Bio-Rad, Hercules, USA).

\section{Antiserum production and Western blot analysis}

Antiserum against rVP466 was produced in white rabbit $(2.5 \mathrm{~kg})$ as described by Ha et al. [3]. The immunoglobulin (IgG) fraction was purified by protein A-Sepharose (Bio-Rad, Hercules, USA). Enzyme-Linked Immunosorbent Assay (ELISA) was carried out to determine the titers of rVP466 antiserum as described by Harlow at al. [4]. The rVP466 antiserum was considered positive when the average reading of the duplicate wells was at least twice higher than the average reading for the negative serum $(\mathrm{P} / \mathrm{N}$ ratio $\geq 2)$.

The Western blot analysis was carried out by the method of Ha et al. [3]. The result was identified with BCIP/NBT liquid substrate system (Sigma-Aldrich, St. Louis, USA).

\section{Neutralization assay}

For the neutralization challenge, the healthy shrimps without the virus were divided into six groups as described in Table 1. The preimmune serum was included as a control for the effect of a preimmune serum on shrimp mortality. The WSSV stocks $\left(1 \times 10^{4}\right.$ dilute $)$ with 3 different doses of rVP466 antiserum or rabbit preimmune serum were mixed for $1 \mathrm{hr}$ at $28^{\circ} \mathrm{C}$ on the shaking rocker. Fifty microliter mixtures of WSSV and antiserum were intramuscularly injected into shrimp. The experiments were conducted in triplicate. After the injection, the shrimp mor- 
Table 1. Contents of experimental groups used in the neutralization assay

\begin{tabular}{|c|c|c|}
\hline Experimental group & Contents & No. of shrimp \\
\hline Negative control & $50 \mu \mathrm{l}$ PBS & $15 \times 3$ \\
\hline Positive control & $25 \mu \mathrm{l}$ WSSV stock $+25 \mu \mathrm{l}$ PBS & $15 \times 3$ \\
\hline Preimmune serum & $25 \mu \mathrm{l}$ WSSV stock $+25 \mu \mathrm{l}$ Preimmune serum & $15 \times 3$ \\
\hline WSSV:rVP466 antiserum $=1: 0.01$ & $25 \mu \mathrm{l} \mathrm{WSSV}$ stock $+0.25 \mu \mathrm{l}$ rVP466 antiserum $+24.75 \mu \mathrm{l}$ PBS & $15 \times 3$ \\
\hline WSSV:rVP466 antiserum $=1: 0.1$ & $25 \mu \mathrm{l} \mathrm{WSSV}$ stock $+2.5 \mu \mathrm{l} \mathrm{rVP466}$ antiserum $+22.5 \mu \mathrm{l} \mathrm{PBS}$ & $15 \times 3$ \\
\hline WSSV:rVP466 antiserum = 1:1 & $25 \mu \mathrm{l}$ WSSV stock $+25 \mu \mathrm{l}$ rVP466 antiserum & $15 \times 3$ \\
\hline
\end{tabular}

tality was monitored daily.

\section{Results and Discussion}

\section{Production of recombinant envelop protein VP466 (rVP466)}

The VP466 protein of WSSV is one of the structural proteins existing in envelop of virus. The production of rVP466 protein was carried out from the cloned E. coli. After the cloning, digestions of pCold-VP466 were carried out with BamH I and Hind III and the restriction map was prepared as shown in Fig. 1. The 1381 bp fragment of the VP466 gene was observed, indicating correct construction of pColdVP466. The protein was expressed by induction at $37^{\circ} \mathrm{C}$ for $3 \mathrm{hr}$ with $0.5 \mathrm{mM}$ IPTG as an optimal expression condition. After the expression, the purification of rVP466 was carried out with Ni-Sepharose and Amicon Ultra membrane. The total soluble and insoluble proteins were run by SDS-PAGE (12\% acrylamide gel) as shown in Fig. 2A. The expressed protein band of VP466 was observed at the expected position of $50 \mathrm{kDa}$. In the Western blot analysis, the rVP466 anti- serum showed a clear reaction with rVP466 corresponding to VP466 protein as shown in Fig. 2B.

Purification of (His) 6 -tagged VP466 was carried out using Ni-Sepharose high performance resin open column (GE Healthcare Bio-science, Uppsala, Sweden) and concentration of VP466 was performed using Amicon Ultra 30K (Millipore, Bedford, USA). The total protein extract shows the thick band of VP466 at $50 \mathrm{kDa}$, however there were many contaminating protein with concentration of $6.0 \mathrm{mg} / \mathrm{ml}$ as shown in Fig. 2C. After the affinity resin column to His-tag, contaminating proteins were removed, however the protein concentration was decreased to $0.7 \mathrm{mg} / \mathrm{ml}$. Concentration with Amicon Ultra $30 \mathrm{~K}$ increased the protein concentration to $1 \mathrm{mg} / \mathrm{ml}$ as shown in Fig. 2C lane 6. The purified VP466 was used for the production polyclonal antiserum in the rabbit with immunization and 2 boosting shots. The antiserum produced from the rabbit was used for the Western blot as shown in Fig. 2B.

Based on these results, the recombinant envelop protein rVP466 from WSSV genomic DNA and the antiserum raised against rVP466 were successfully produced and the rVP466

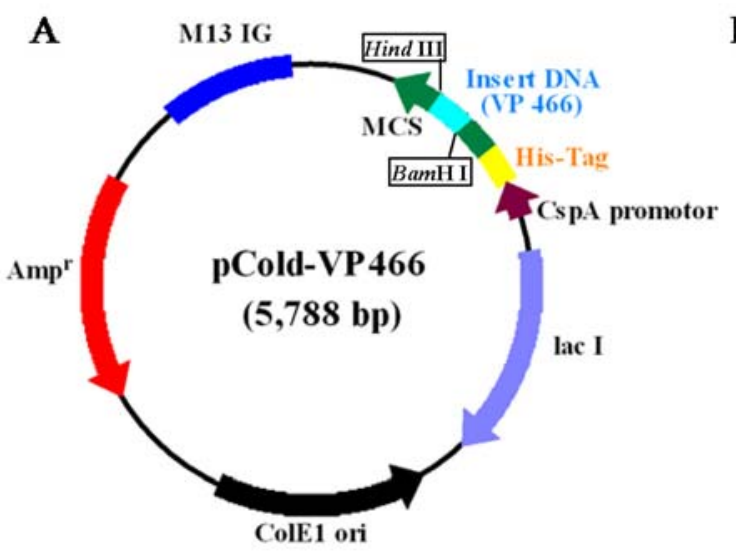

\section{B}

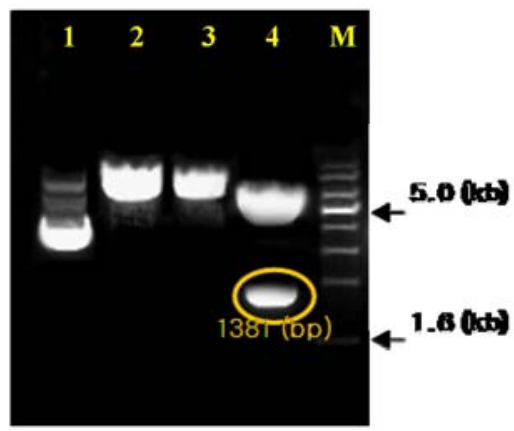

Fig. 1. Recombinant plasmid pCold-VP466 and restriction patterns. (A) pCold-VP466 with the size of 5788 bp, (B) restriction patterns using BamH I and Hind III in 0.8\% agarose gel. M, 1 kb DNA ladder marker; lane 1, Uncut recombinant plasmid pCold-VP466; lane 2, One cut fragment with Bam H I; lane 3, One cut fragment with Hind III; lane 4, Two cut fragments with Bam $\mathrm{H}$ I and Hind III. 

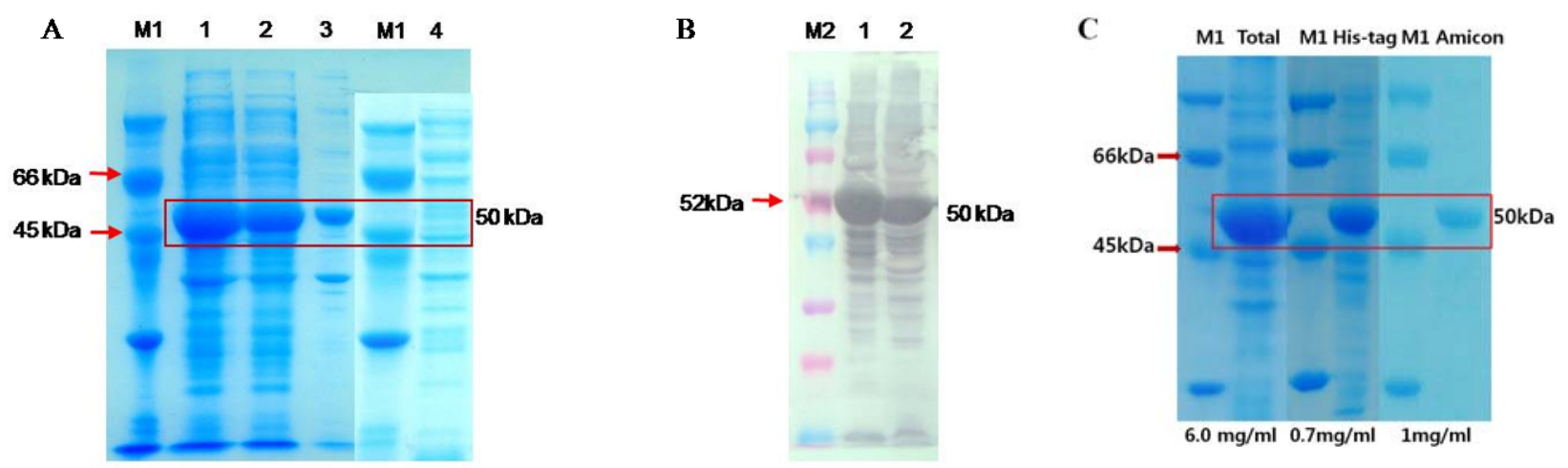

Fig. 2. Identification of expressed recombinant protein rVP466. (A, C) SDS-PAGE (B) Western blot analysis. M1, Protein molecular weight standard marker; M2, ProSieve-Color protein ladder marker; lane 1, total cell extract; lane 2, soluble fraction; lane 3, insoluble fraction; lane 4, empty vector (mock); Total, total cell extract; His-tag, purified protein using affinity resin column to His-tag; Amicon, concentrated protein using Amicon Ultra 30K.

antiserum had a proper immune reactivity with the antigen, rVP466.

Titration of WSSV for the determination of challenge pressure

For the determination of dilution ratio resulting in 100\% mortality of shrimp for desired period of experiments, in vivo virus titration was performed. As shown in Fig. 3, the results of in vivo titration showed $50-100 \%$ mortalities in all tested groups at 14 days of post challenge. Administration of virus dilutions of $1 \times 10^{1}, 1 \times 10^{2}, 1 \times 10^{3}$ and $1 \times 10^{4}$ resulted in $100 \%$ mortality in less than 11 days of post challenge.

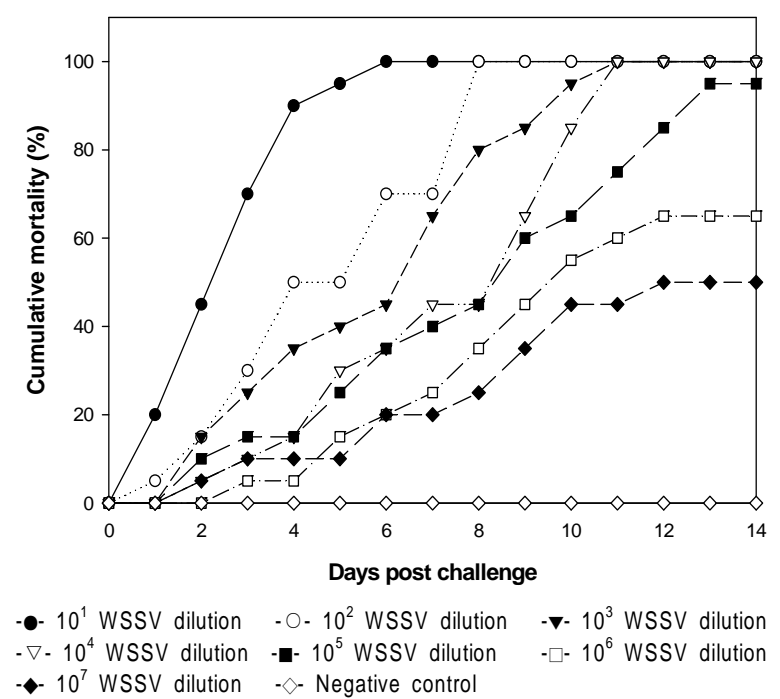

Fig. 3. WSSV titration for the determination of optimal challenge pressure. Twenty-five microliters of $1 \times 10^{1}, 1 \times 10^{2}, 1 \times 10^{3}$, $1 \times 10^{4}, 1 \times 10^{5}, 1 \times 10^{6}$ and $1 \times 10^{7}$ diluted stock was injected intramuscularly into Penaeus chinensis.
However, the dilutions of $1 \times 10^{5}, 1 \times 10^{6}$ and $1 \times 10^{7}$ resulted in final mortalities of $95 \%, 65 \%$ and $50 \%$ at 14 days of post challenge. Therefore, the virus dilution of $1 \times 10^{4}$ was chosen as the optimal challenge pressure for the neutralization experiment.

\section{WSSV neutralization with rVP466 antiserum}

The rVP466 antiserum from white rabbit was used for in vivo neutralization using the shrimp. As shown in Fig. 4, the shrimps in the positive control showed $100 \%$ mortality

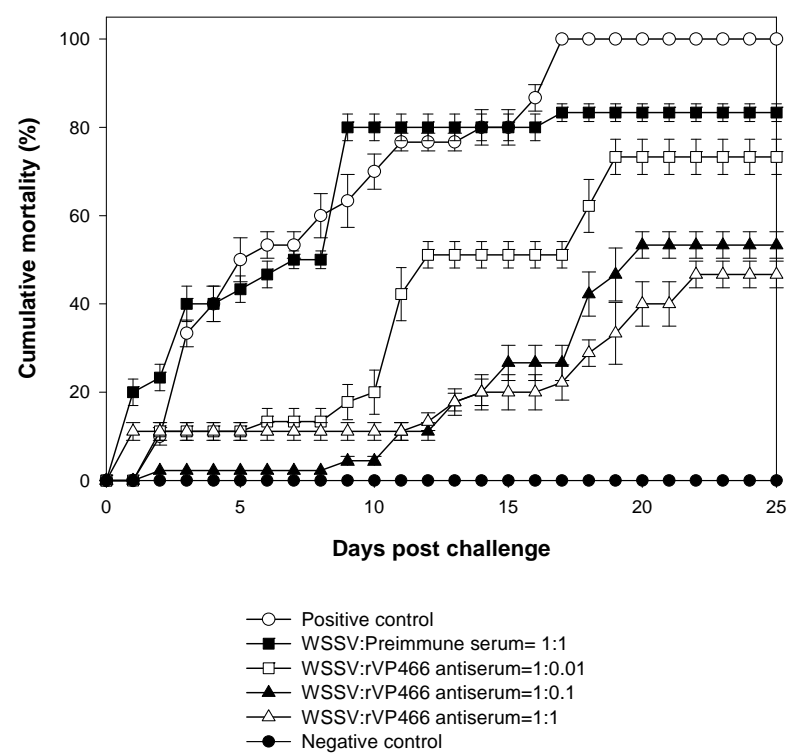

Fig. 4. In vivo neutralization of WSSV infection in Penaeus chinensis with rVP466 antiserum and WSSV. Each point represented the mean of triplicate tests. The six groups were described in Table 1. 
at 17 days of post challenge. The shrimps challenged with the mixture of WSSV and preimmune serum showed $83 \%$ mortality of shrimp at 25 days of post challenge. When the shrimps challenged with the 3 different mixtures of WSSV and rVP466 antiserum with 1:0.01, 1:0.1 and 1:1 ratios, the shrimp mortalities showed $73 \%, 53 \%$ and $46 \%$ at 25 days of post challenge, respectively. And no shrimp died in the negative control. These results indicated that the WSSV could be neutralized by the rVP466 antiserum in a dose-dependent manner.

Antibodies against the individual viral envelop proteins were used in neutralization assays to study the roles of envelop proteins in virus entry [12]. Information obtained from the neutralization assays has even led to passive immunization strategies for vertebrates [8]. It has been reported that rabbit serum containing antibodies against some major envelop proteins such as VP28 delayed WSSV-induced mortality of P. monodon [9]. VP28 is one of the major envelop proteins in WSSV and involved in the systemic infection to shrimp [7]. However, VP28 is not a single protein for the attachment to the host cell. The large DNA virus requires attachment protein complex for the cell entry of virus [5]. Based on the results of neutralization effect of the antiserum against VP466 to WSSV, it can be confirmed that VP466 of WSSV may also be involved in the entry or attachment of WSSV to shrimp cell. In vivo neutralization assay with antiserum against rVP466 showed similar survival ratio to that with VP28. Results suggest that envelop protein VP466 is also involved in the initial step of WSSV infection similar to VP28.

Further studies with other envelop proteins are required for the systemic analysis of the virus entry to cell for the infection.

\section{Acknowledgement}

This work was supported by Basic Science Research Program through the National Research Foundation of Korea (NRF) funded by the Ministry of Education, Science and Technology (MEST) (KRF-2008-F00084). Dr, Yeong-Jin Kim was financially supported by Pukyong National University in the 2008 Post-Doc. program. Soo-Jung Gong and Mi-Ran Choi receive financial support by the fund from Brain Busan 21 project of Metropolitan City of Busan.

\section{References}

1. Burton, D. R. 2002. Antibodies, viruses and vaccines. Natl. Rev. Immunol. 2, 706-713.

2. Escobedo-Bonilla, C. M., V. Alday-Sanz, M. Wille, P. Sorgeloos, M. B. Pensaert, and H. J. Nauwynck. 2008. A review on the morphology, molecular characterization, morphogenesis and pathogenesis of white spot syndrome virus. J. Fish Dis. 31, 1-18.

3. Ha, Y. M., Y. I. Kim, K. H. Kim, and S. K. Kim. 2008. Neutralization of white spot syndrome virus (WSSV) for Penaeus chinensis by antiserum raised against recombinant VP19. J. Environ. Biol. 29, 513-517.

4. Harlow, E. and D. Lane. 1988. Antibodies: a laboratory manual. NY, USA: Cold Spring Harbor Laboratory Press, Cold Spring Harbor.

5. Herold, B. C., D. WuDunn, N. Soltys, and P. G. Spear. 1991. Glycoprotein $C$ of herpes simplex virus type 1 plays a principal role in the adsorption of virus to cells and in infectivity. J. Virol. 65, 1090-1098.

6. Huahua, D., Z. Xu, X. Wu, W. Li, and W. Dai. 2006. Increased resistance to white spot syndrome virus in Procambarus clarkii by injection of envelop protein VP28 expressed using recombinant baculovirus. Aquaculture 260, 39-43.

7. Musthaq, S. S., K. Yoganandhan, R. Sudhakaran, S. R. Kumar, and A. S. Hameed. 2006. Neutralization of white spot syndrome virus of shrimp by antiserum raised against recombinant VP28. Aquaculture 253, 98-104.

8. Schofield, D. J., J. Glamann, S. U. Emerson, and R. H. Purcell. 2000. Identification by phage display and characterization of two neutralizing chimpanzee monoclonal antibodies to the hepatitis E virus capsid protein. J. Virol. 74, 5548-5555.

9. Van Hulten, M. C. W., J. Witteveldt, M. Snippe, and J. M. Vlak. 2001. White spot syndrome virus envelop protein VP28 is involved in the systemic infection of shrimp. Virology. 285, 228-233.

10. Venegas, C. A., L. Nonaka, K. Mushiake, T. Nishizawa, and K. Muroga. 2000. Quasi-immune response of Penaeus japonicus to penaeid rod-shaped DNA virus (PRDV). Dis. Aquat. Org. 42, 83-89.

11. Vlak, J. M., J. R. Bonami, T. W. Flegel, G. H. Kou, D. V. Lightner, C. F. Loh, P. C. Loh, and P. W. Walker. 2005. Nimaviridae. Academic Press, London, UK: Virus Taxonomy: Eighth Report of the International Committee on Taxonomy of Viruses.

12. Volkman, L. E. and P. A. Goldsmith. 1985. Mechanism of neutralization of budded Autographs californica nuclear polyhedrosis virus by a monoclonal antibody: Inhibition of entry by adsorptive endocytosis. Virology. 143, 185-195.

13. Witteveldt, J., C. C. Cifuentes, J. M. Vlak, and Van M. C. W. Hulten. 2004. Protection of Penaeus monodon against white spot syndrome virus by oral vaccination. J. Virol. 78, 2057-2061. 
14. Wu, J. L., T. Nishioka, K. Mori, T. Nishizawa, and K. A. Muroga. 2002. A time-course study on the resistance of
Penaeus japonicus induced by artificial infection with white spot syndrome virus. Fish Shellfish Immunol. 13, 391-403.

\section{초록 : 흰반점바이러스(WSSV)의 중화를 위한 재조합단백질 rVP466의 항혈청 생산}

공수정 ${ }^{1} \cdot$ 김영진 · 최미란 · 김성구*

(부경대학교 생물공학과, ${ }^{1}$ (주)바이넥스 연구소)

본 연구는 WSSV의 재조합단백질 rVP466에 대하여 생산된 항혈청을 사용하여 WSSV에 대한 neutralization (중화) 효과를 확인하고자 수행하였다. 먼저 재조합단백질 rVP466의 생산을 위해 WSSV의 구성단백질 VP466을 암호화하는 유전자인 VP466을 포함하는 재조합 플라스미드 pCold-VP466을 제작한 다음 이것을 발현용 숙주인 E. coli RIPL에서 발현하였다. 발현된 rVP466에 대한 항혈청은 토끼를 사용하여 생산하였으며, 항원 rVP466에 대 한 특이면역반응은 Western blot을 통해 확인하였다. WSSV에 대한 항혈청의 중화효과를 확인하기 위해 항혈청 과 반응시킨 바이러스액 $\left(1 \times 10^{4}\right.$ 배로 희석된 WSSV)을 이용하여 실험용 새우(Penaeus chinensis)에게 주사 감염을 통해 공격실험(challenge test)을 수행하였다. 실험 결과, WSSV로 공격실험한 감염대조구(positive control)의 새 우들은 감염 후 17 일째에 $100 \%$ 누적폐사율을 보였으며, preimmune serum과 WSSV의 혼합액을 challenge한 preimmune control의 새우들은 감염 후 25일째에 $83 \%$ 의 누적폐사율을 보였다. WSSV와 rVP466 항혈청을 1:0.01, 1:0.1, 1:1로 혼합한 액으로 challenge한 새우들은 감염 후 25 일째에 각각 $73 \%, 53 \%, 46 \%$ 의 누적폐사율을 보였다. 이상의 결과를 통해 WSSV가 rVP466 항혈청에 의해 농도의존적으로 neutralization됨을 확인하였으며, 이는 WSSV 감염과정에 VP466이 관여함을 나타내는 것이다. 